\title{
AZ ALAKÍTÁSI KEMÉNYEDÉS HATÁSA A HÚZÁSI VISZONYRA MÉLYHÚZÁSNÁL
}

\section{EFFECT OF HARDENING ON THE LIMIT DRAWING RATIO}

\author{
Ugró Máté, Gonda Viktor \\ Óbudai Egyetem, Bánki Donát Gépész és Biztonságtechnikai Mérnöki Kar, 1081 \\ Budapest, Népszínház u. 8.Tel.+36-1-6665310,gonda.viktor@bgk.uni-obuda.hu
}

\begin{abstract}
Determination of the limit drawing ratio by finite element modeling is presented for deep drawing without a blank holder. First we examined the effect of the hardening for linear hardening material model at different specific sheet thicknesses, and then we applied real flow curves for the calculations. We demonstrated, that limit drawing ratio increases for increasing hardening, decreasing static yield limit, and decreasing sheet thickness (if wrinkling not considered).
\end{abstract}

Keywords: deep drawing, limit drawing ratio, finite element method.

\section{Összefoglalás}

A húzási viszony meghatározásának végeselemes módját mutatjuk be ráncgátló nélküli mélyhúzás esetére. Vizsgáljuk a keményedés hatását egyrészt idealizált esetben lineárisan keményedő anyagmodell alkalmazásával, különböző fajlagos lemezvastagságok esetén, valamint valós anyagmodell alkalmazásával. Megállapítható, hogy a húzási viszonynak kedvez a nagyobb keményedési együttható, kisebb statikus folyáshatár, valamint a kisebb lemezvastagság (a ráncosodás figyelembe vétele nélkül).

Kulcsszavak: mélyhúzás, húzási viszony, végeselemes módszer.

\section{Bevezetés}

A mélyhúzás technológiai tervezése során a húzási viszony az egyik fontos kiinduló adat, amely közvetett módon mutatja, hogy pl. a kezdőhúzásnál egy adott csészeátmérőhöz milyen palástmagasságot lehet létrehozni. A húzási viszonyt (limit drawing ratio, LDR) konkrétan a terítékátmérő és a csészeátmérö hányadosával határozzuk meg, ajánlott értékeit ráncgátlós vagy ráncgátló nélküli, első- vagy továbbhúzás esetére, különböző fajlagos lemezvastagság értékekhez táblázatokban adják meg a tervezési segédletek [1]. Elméleti úton egyszerüsítések alkalmazásával meghatározható egy ideális érték (amely: e = 2,7182). Kísér- letileg egy adott vastagságú és anyagminőségü lemezanyagra csészehúzó vizsgálattal határozható meg a húzási viszony, mely jellemzően 1,5-2,3 körüli értékü. A húzási viszony értéke növelhetö, ha a teríték csészefenék közeli részét helyileg keményítjük, vagy a perem felőli részét lágyítjuk pl. lokális lézeres hőkezeléssel [2]. A húzási viszony itt becsülhető numerikus számítással.

Különböző anyagminőségek húzhatóságának vizsgálatával megmutatható, hogy jellemzően a nagyobb alakítási keményedésü lemez jobban mélyhúzható [3].

Ebben a dolgozatban a húzási viszony meghatározásának végeselemes módját mutatjuk be ráncgátló nélküli mélyhúzás 
esetére. Vizsgáljuk a keményedés hatását egyrészt idealizált esetben lineárisan keményedő anyagmodell alkalmazásával, különböző fajlagos lemezvastagságok esetén, valamint valós anyagmodell alkalmazásával.

\section{A modell felépítése}

A tengelyszimmetrikus csésze mélyhúzásának a modellezéséhez a meridián metszetben a húzás geometriai adatai felvehetők (1. ábra). A MARC student edition végeselemes programban egy paraméteres ún. procedure fájlból generáltuk a geometriát, az alábbi paramétereket definiálva:

$\mathrm{d}_{\mathrm{B}}$ : csésze belső átmérō, bélyegátmérő

$\mathrm{r}_{\mathrm{B}}$ : bélyeg lekerekítési sugár

$\mathrm{d}_{\mathrm{M}}$ : húzógyürü átmérő

$\mathrm{r}_{\mathrm{M}}$ : húzógyürü lekerekítési sugár

$\mathrm{D}_{0}$ : terítékátmérő

$\mathrm{s}_{0}$ : lemezvastagság

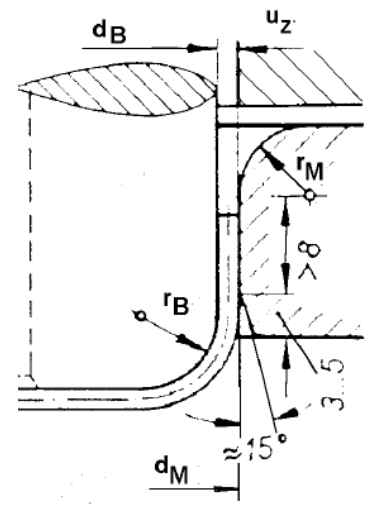

1. ábra. A geometriai paraméterek mélyhúzásnál

Alapvetően a 17 mm-es bélyegátmérő húzáshoz $0,5 \mathrm{~mm}$ és $1 \mathrm{~mm}$-es lemezvastagság esetén (kb. 1,5 és 3 fajlagos lemezvastagság) kerestük a terítékátmérőt. A szimmetriát kihasználva a meridián metszet felét modelleztük síkban, a szerszámot (húzóbélyeg és húzógyürü) merevnek, a lemezt izotróp, rugalmas-képlékeny anyagnak tekintettük Mises folyási feltételt használva.
A szimmetriát egyrészt az elemtípusban, másrészt kényszerrel határoztuk meg (2. ábra). A bélyeg mozgását állandó sebességünek vettük, a folyásgörbék nem sebességfüggők. A súrlódási tényezőt 0,1-re vettük fel.

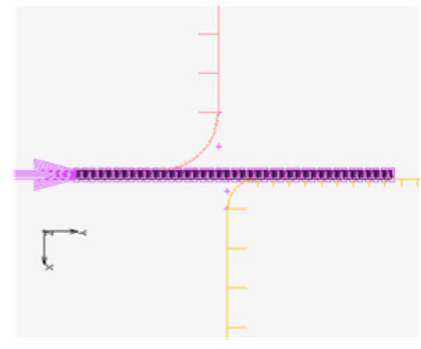

2. ábra. $A$ végeselemes modell felépitése
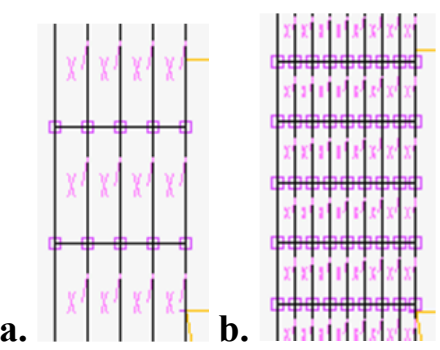

3.ábra.: Durva (a) és süritett háló (b)

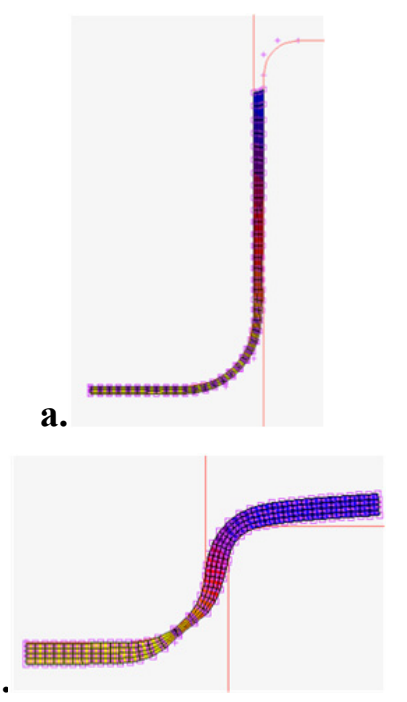

4. ábra.: Sikeres (a) és sikertelen (b) húzás 
A modell hálófüggését két hálózással vizsgáltuk (3. ábra): a lemezvastagságban 4 vagy 8 elemet létrehozva. Lényeges különbséget nem találtunk az eredményekben, a sürübb hálózást használtuk a továbbiakban. A számítást adott lemezvastagság és szerszámgeometria esetén a terítékátmérő változtatásával futtattuk, jellegzetes kimenetek a 4. ábrán láthatók. A 4a ábrán sikeresnek tekintjük a húzást, ha a peremet teljesen be tudjuk húzni, valamint sikertelennek (4b ábra), ha peremet nem tudjuk behúzni. A kialakuló feszültséget nem vizsgáljuk, tehát szakítószilárdságot nem definiáltunk. A húzási viszonyt a még éppen sikeres húzás terítékátmérőjével számítjuk.

\section{Eredmények és következtetések}

\subsection{Elméleti folyásgörbék}

A lineáris folyásgörbe modellje:

$$
k_{f}=R_{p}+H \lambda_{\ddot{o}}
$$

ahol $k_{f}[\mathrm{MPa}]$ az alakítási szilárdság, $R_{p}$ [MPa] a statikus folyáshatár, $H[\mathrm{MPa}] \mathrm{a}$ lineáris keményedési együttható, $\lambda_{\ddot{o}}$ az öszszehasonlító alakváltozás. Három féle keményedési együtthatót definiáltunk: 50, 300, $900 \mathrm{MPa}$ értékekkel, valamint kétféle statikus folyáshatárt 200 és 1000 MPa értékekkel, összesen négy folyásgörbét meghatározva (5. ábra).

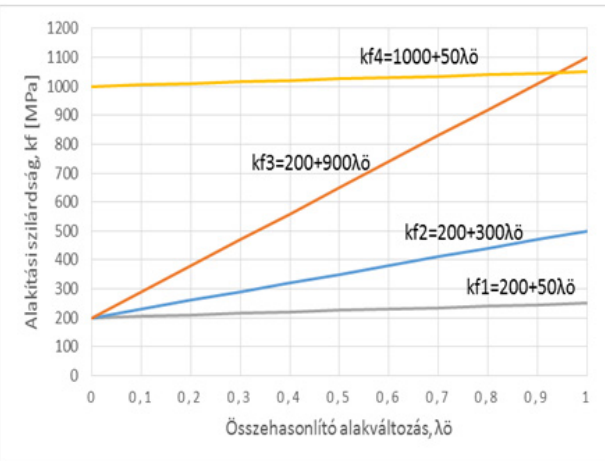

5. ábra. Folyásgörbék a lineárisan keményedö anyagmodell esetén
A 6. ábra $k_{\mathrm{f} 2}$ folyásgörbéjével 0,5 és 1 mm-es lemezvastagság és $18 \mathrm{~mm}$-es terítékátmérő esetén a az összehasonlító alakváltozást ábrázoltuk a teríték sugarának a függvényében a húzás végén.

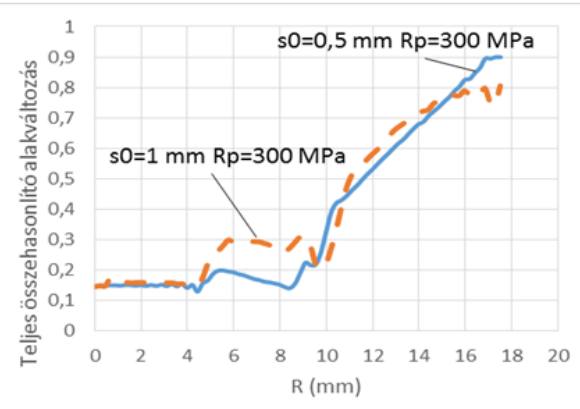

6. ábra. Az összehasonlitó alakváltozás a teriték sugarának függvényében vékony $\left(s_{0}=\right.$ $0,5 \mathrm{~mm})$ és vastag $\left(s_{0}=1 \mathrm{~mm}\right)$ lemez esetén $H=300$ MPa keményedésnél.

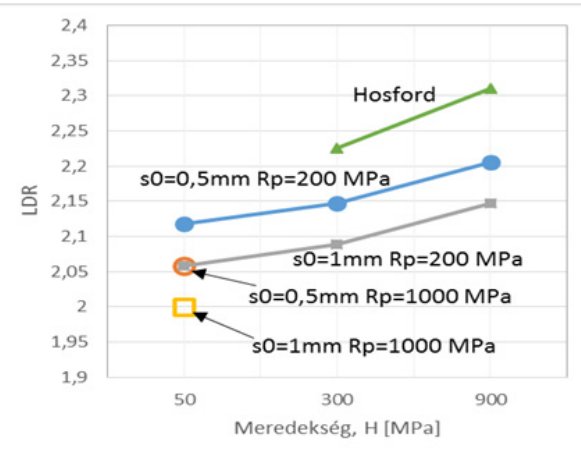

7. ábra. A húzási viszony az lineáris keményedési meredekség függvényében

A négy folyásgörbéhez két fajlagos lemezvastagsággal lefuttatott számítások eredményeként összesen 8 húzási viszonyt határoztunk meg a 2-2,2 közé eső tartományban, melyeket a 7. ábrán mutatunk be. A futtatások során megfigyeltük a háló sürüségének hatását. A 8 eredmény közül 3 esetben segített a sürübb háló használata, ekkor további $0,5 \mathrm{~mm}$-rel nagyobb terítéket tudtunk lehúzni mely csak kis mértékben növelte a húzási viszony értékét. A 7. ábrán 
további két húzási viszony látható: ábrázoltuk a Logan, Meuleman és Hosford által készített diagram azonos meredekséghez tartozó pontjait is [3].

$\mathrm{Az}$ eredményeket összegezve megállapítható, hogy nagyobb keményedési együtthatóval rendelkező anyag jobban húzható, de a nagyobb statikus folyáshatás csökkenti a húzhatóságot. A lemezvastagság csökkentése is növeli a húzási viszonyt. Megjegyzendő, hogy a ráncosodást a modell nem tartalmazza.

\subsection{Valós folyásgörbék}

A folyásgörbét az egyszerü hatványgörbével vettük figyelembe:

$$
k_{f}=C \lambda_{\ddot{\mathrm{o}}}^{n}
$$

ahol $C$ a keményedési együttható, $n$ a keményedési kitevő. A $\lambda_{\ddot{o}}=0$ értékhez a statikus folyáshatár értékét vettük figyelembe. Az öt vizsgált anyagminőségre az anyagjellemzők az 1. táblázatban találhatók, a folyásgörbék a 8. ábrán láthatók. A lemezvastagság értékét itt $0,5 \mathrm{~mm}$-nek vettük. A húzási fokozat értékei 2,17-2,19-es tartományba esnek, a keményedési kitevő függvényében a 9. ábrán láthatók. $\mathrm{Az}$ eredmények a 7. ábrán a $\mathrm{H}=300 \mathrm{MPa}$ meredekséghez kapott értékekkel vethetők össze. A választott anyagminőségekre kapott értékek egy jóval szükebb eredmény tartományban helyezkednek el, mint az extrém tartományt lefedő idealizált folyásgörbék eredményei.

1. Táblázat. Folyásgörbe paraméterek és statikus folyáshatár a vizsgált anyagminőségekhez

\begin{tabular}{|l|l|l|l|}
\hline & $\mathrm{C}[\mathrm{MPa}]$ & $\mathrm{n}$ & $\mathrm{k}_{\mathrm{f} 0}[\mathrm{MPa}]$ \\
\hline $\mathrm{CuE}$ & 364,71 & 0,27 & 82,4 \\
\hline A199,5 & 145,63 & 0,1995 & 31,4 \\
\hline AlMgSi1 & 229,94 & 0,166 & 71,3 \\
\hline AlMg3 & 414,98 & 0,2245 & 139,3 \\
\hline DC03 & 524 & 0,2243 & 200 \\
\hline
\end{tabular}

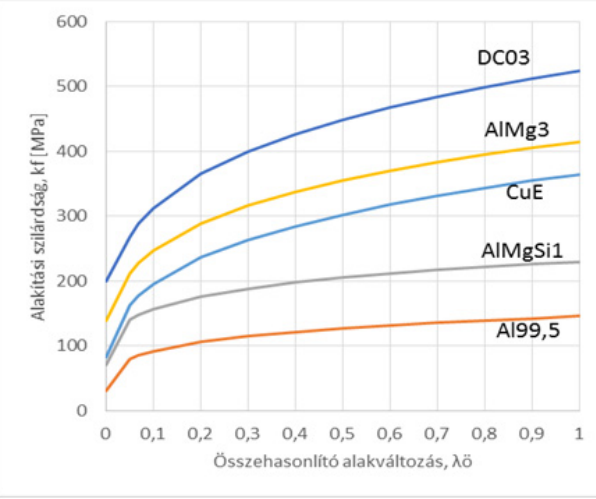

8. ábra. Valós folyásgörbék különbözö vizsgált anyagminöségekhez

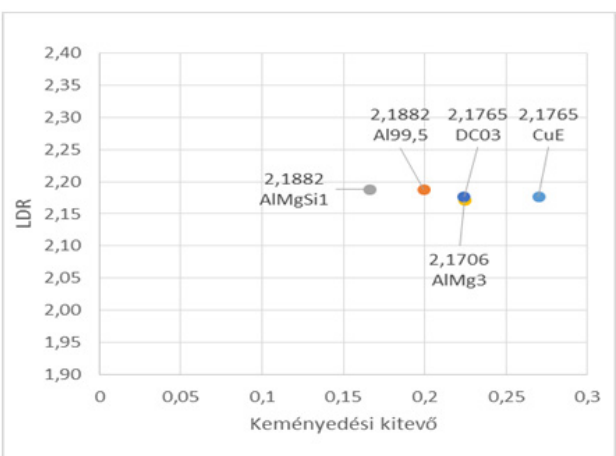

9. ábra. A húzási viszony értékek a valós folyásgörbékhez

\section{Köszönetnyilvánítás}

A dolgozat a Bolyai János Kutatási Ösztöndíj támogatásával készült.

\section{Szakirodalmi hivatkozások}

[1] Horváth László: Mélyhúzás technológia tervezése. Oktatási segédlet, Óbudai Egyetem, Bánki Donát Gépész- és Biztonságtechnikai Mérnöki Kar, 2009.

[2] C.J. Tan et al.: Estimating surface hardening profile of blank for obtaining high drawing ratio in deep drawing process using FE analysis, IOP Conf: Mat. Sci and Eng 103, 012047, pp. 1-6, 2015.

[3] W.F. Hosford, R.M. Caddell: Metal forming, mechanics and metallurgy. Third Edition. Cambridge University Press, pp. 224-228. 2007. 